\title{
Mudanças fáceis e difíceis
}

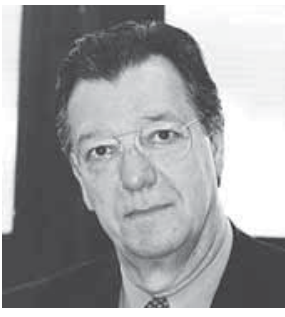

Carlos Osmar Bertero

FGVEAESP

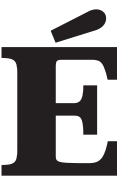

difícil negar que o ser humano é mais conservador do que adepto das mudanças. Isso mostra por que as mudanças não são fáceis de realizar e porque o tópico de resistências à mudança tornou-se clássico em administração. Sempre falado, debatido, mas nunca satisfatoriamente solucionado.

A mudança éuma necessidade, ea maneira como é recebida dependerá de vários fatores. Pode-se prometer que as mudanças são sempre para melhorar as coisas, ou seja, todos se beneficiarão delas. Mas, mesmo em tom tão otimista, sempre há uma dose de desconfiança por parte da maioria.

A realidade indica que a maioria das mudanças implica piorar para depois melhorar. E os ônus e benefícios não se distribuem igualmente. Há os que só são prejudicados com as mudanças e outros que apenas se beneficiam. Quando se reestrutura uma empresa, há perdas sob a forma de demissões, prestígio, poder estatus para alguns. Poderá, para outros, haver apenas benefícios porque terão uma situação organizacional melhorada, com uma empresa que se espera seja mais sólida e equilibrada.

E há as mudanças que são as mais difíceis de realizar e as geradoras das maiores resistências. Paradoxalmente, mesmo sendo as mais necessárias, são procrastinadas. As características dessas mudanças são que acarretam ônus imediatos para a maioria e apenas uma remota perspectiva de melhoria, mas apenas quando os que arcaram com o ônus já não mais estiverem por aqui para usufruir dos benefícios.

Evidentemente, estamos falando aqui de reformas previdenciárias, seja no setor público, seja nos fundos privados de pensão. À medida que a longevidade aumenta, os recursos escasseiam para poder atender a vidas mais longas com desfrute dos benefícios. Mudanças previdenciárias significam necessariamente adiamento do desfrute, pelo aumento da idade mínina e de outras condições para a aposentadoria, e também o aumento imediato das contribuições de todos os que fazem parte do sistema.

Para todas essas desvantagens, que vantagens são oferecidas? Dir-se-á que a médio e longo prazo se impedirá que o sistema soçobre. Dir-se-á ainda que, se o sistema for público, deixará de consumir recursos fiscais que poderão ter outras destinações, como novos investimentos, redução do endividamento publico e do seu serviço, deixando de onerar as gerações futuras.

Todas essas justificativas são nobremente inspiradas, mas, além de conservador com relação à mudança, o ser humano é também imediatista e pouco se comove com o futuro. É antes o inverso o que ocorre: comove-se cada vez menos à medida que aumenta a distância entre sacrifícios presentes e benefícios futuros. 